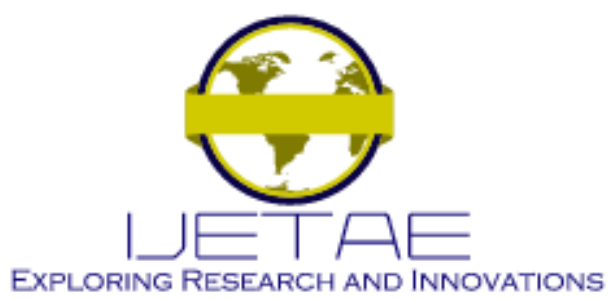

International Journal of Emerging Technology and Advanced Engineering

Website: www.ijetae.com (E-ISSN 2250-2459, Scopus Indexed, ISO 9001:2008 Certified Journal, Volume 12, Issue 01, January 2022)

Manuscript Received: 02 December 2021, Received in Revised form: 04 January 2022, Accepted: 10 January 2022

DOI: 10.46338/ijetae0122_08

\title{
Implementation of a Remote Activation Alarm System by the Citizens of the District of Carabayllo, Lima-Peru
}

\author{
Dan Alva-Castillo ${ }^{1}$, Brian Meneses-Claudio ${ }^{2}$, Alexi Delgado ${ }^{3}$ \\ ${ }^{1,2}$ Universidad de Ciencias y Humanidades \& Av. Universitaria 5175, Los Olivos 15304 \\ ${ }^{3}$ Pontificia Universidad Católica del Perú \& Av. Universitaria 1801, San Miguel 15088
}

\begin{abstract}
Citizen insecurity is a reality with which we must coexist, the cities of Latin America are among the most violent and insecure in the world. According to the statistics of the National Police of Peru, they report that by 2017 the crimes of theft or robbery were the most common because they had a monthly average of 15348 complaints, equivalent to $66.9 \%$ of the total crimes nationwide. The INEI (National Institute of Statistics and Informatics) revealed that in the same year the district of Carabayllo obtained $1.85 \%$ of the total complaints in Metropolitan Lima, occupying the 17th place in the ranking of districts with the highest number of complaints for this crime. That is why in the present research work a way to counteract these criminal acts was proposed, the first thing is to be located within the operating range of the $\mathrm{RF}$ module, so that the remote transmission control can activate it, the RF module will be connected to the power outlet and the siren. The siren will oversee persuading the criminal, in addition to alerting the neighbors about the events that are happening. It was obtained as a result that the system fulfills its purpose, it can be alerted in real time about some attempted theft or at the instant of a threat situation, only by pressing the button of the remote control we can persuade the criminals either by scaring them with the sound or with the help of the neighbors.
\end{abstract}

Keywords-- Citizen insecurity, RF Module, Siren, Remote Control.

\section{INTRODUCTION}

The cities and states of Latin America and the Caribbean are among the most violent and insecure in the world. The rate in the regions due to homicides is three times more than the world average and the inhabitants indicate a high sense of insecurity in their regions. More than 40 of the 50 most dangerous cities on the planet are located there. [1]

The International Development Bank estimated in 2000 that Latin America has a cost of violence around $12.1 \%$ of the regional Gross Domestic Product (GDP), these figures are alarming since they are higher than the average social expenditure $(9.1 \%)$ and that of public order and security expenditure $(1.3 \%)$ of the same region.
In 2019 the newspaper El Nacional of the Dominican Republic indicated that every 10 minutes a robbery occurs, this means that every hour at least 6 citizens suffer an assault. Robberies and robberies are an epidemic that is out of control and that affects our society without limits. The statistical numbers of crimes of this type amount to 109154 cases between 2017 and 2018, these figures are of great concern to the Dominican because he fears going out to the street at any time of the day. [2]

In 2017, statistics from the National Police of Peru revealed that crime against property (theft, theft, etc.) is the most common since it has 15348 average monthly complaints, equivalent to $66.9 \%$ of total crimes nationwide. Lima obtained 39\% of the country's complaints with 8905 average cases per month, it is worth noting Metropolitan Lima hosts more than half of the total complaints. [3]

The National Institute of Statistics and Informatics (INEI) in the National Survey of Budget Programs conducted between 2019 and 2021 indicated that in the month of November 2019 the theft of money, wallet and cell phone was equivalent to $14.6 \%$, the attempt to steal money, wallet, and cell phone to $5.5 \%$ and threats and intimidation to $2.2 \%$. In the months of May 2020, the theft of money, wallet and cell phone reached $12.6 \%$, the attempted theft of money, wallet, and cell phone $4.6 \%$ and threats and intimidation $1.4 \%$. Likewise, between the months of November 2020 to April 2021, the theft of money, wallet and cell phone obtained $9 \%$, the attempted theft of money, wallet and cell phone $3.7 \%$ and threats and intimidation $1.6 \%$. [4]

According to the National Institute of Statistics and Informatics (INEI) among the complaints made for crimes against public security in 2017, Carabayllo has a total of 334 complaints of the 17992 total that metropolitan Lima has, which indicates that Carabayllo has $1.85 \%$ of the complaints. Thus, occupying the 17 th place in the ranking of districts with the highest number of complaints for this crime. 


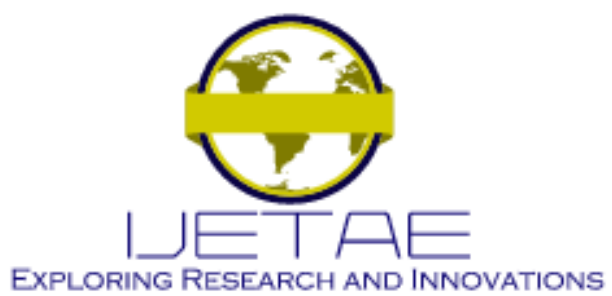

International Journal of Emerging Technology and Advanced Engineering Website: www.ijetae.com (E-ISSN 2250-2459, Scopus Indexed, ISO 9001:2008 Certified Journal, Volume 12, Issue 01, January 2022)

In 2011 Carabayllo had a total of 440 complaints for the commission of crimes, in 2014 this figure increased reaching 525 total complaints and in 2017 this figure was reduced to a total of 334 complaints made. [5]

The objective of this research work is to implement a remote alarm system that allows alerting people in the surrounding homes about the criminal events that are taking place at that time, in this way being able to thwart the criminal action either by persuading the criminal with the alarm or with the help of the people who decide to intervene and apprehend it. For the creation of the system, a $433 \mathrm{MHz}-$ 12VDC RF wireless switch linked to a remote control will be used, the wireless switch must be connected to the 220VAC power outlet and in turn must be connected to a 220VAC - 90W siren. The alarm system must be in a strategic area of the block so that the sound can be heard in a greater amount of the population and thus report the criminal event. All this considering a low cost of implementation and availability in the market in addition to a long scope as indicated in the research work in [9]

Radio frequency links are what predominate today, the equipment that is manufactured has a wireless connection to other equipment, printers with WI-FI, Bluetooth headphones, etc. That is why safety must also improve, for this a KR2201-4 wireless switch of $433 \mathrm{MHz}-220 \mathrm{VAC}$ was used, which can store up to 15 remote controls and have a range of $>50 \mathrm{mts}$ depending on the obstacles that exist. Thanks to the relay that this switch has, it will be possible to alternate in the activation and deactivation of the alarm at a distance.

This research work will detail the steps for the development of the alarm system, the operation of the same, the area or areas to which it will be implemented, the steps that will be conducted for its installation, the results obtained from the tests conducted and finally the conclusions and recommendations of this research work.

\section{LITERATURE REVIEW}

In [6], indicate that in Guayaquil the insecurity that is experienced daily considerably harms the economic, social development, tranquility and security of citizens, this in turn harms the integrity of people. To solve this problem, a lowinvestment remote alarm system was developed to strengthen the security and integrity of citizens.
The system consists of an Opensource main board so called Arduino that is connected to a set of sensors, such as PIR and magnetic switches, this system is supported by a module called SIM900 that intercommunicates with the main board to send text messages to cell numbers, in the case the alarm is activated. According to the results obtained from the surveys of the population on the opinion about the alarm system, it was noted that it represents a very reliable percentage level, as well as having the presence of the national police, this is because police patrols are not frequent enough or even in some areas are null so the system that was implemented is very feasible for this type of situations. They conclude that the current situation in the urban-marginal sectors of Guayaquil in relation to crime is highly worrying since it is constantly increasing and causes great concern in the population, this alarm system will be a support for the solution of this problem that is lived in Guayaquil and can help reduce statistics.

In [7],they point out that currently crimes of various types are shown and not only from Ecuador, these crimes are worldwide. According to the latest study conducted by the company CEDATOS in $2017,65 \%$ of people or one of their relatives were victims of a criminal act. For this, the authors propose to develop an alarm system at the community level, using mobile communications technology to prevent and alleviate robberies in homes. The community alarm system will have GSM and RF technologies, which will optimize the use of the alarm system. GSM technology will help access a cellular platform (Movistar, Claro, or CNT), to be able to send text messages from the sending equipment to the mobile equipment of the subscribers, in this way they will be able to know where the signal was emitted and the data of the user who activated them (name, telephone number). In addition, through mobile equipment, the customer can turn on the alarm without consuming their balance, it will only be necessary to call once, and the system will automatically detect that the cell phone number is registered and will proceed to start the process of activating the alarm. As results denote that it was possible to meet the established goals, a proof of that were the surveys that were conducted in which the level of reduction of crime and the perception of insecurity in citizens is shown. The surveys were conducted on two occasions, after installation of the alarms and after their installation. 


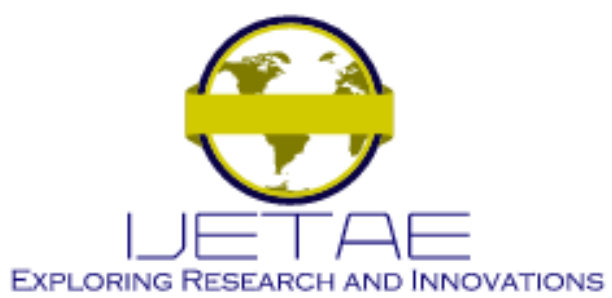

International Journal of Emerging Technology and Advanced Engineering Website: www.ijetae.com (E-ISSN 2250-2459, Scopus Indexed, ISO 9001:2008 Certified Journal, Volume 12, Issue 01, January 2022)

As a conclusion of the project, the help for the reduction of the crime rate in Ecuador by the control societies is evident, thanks to the fact that they have been able to study various community alarm projects, however, it should be noted that these projects have only been carried out in certain strategic sectors of the city and according to studies, the level of crime has a greater impact on the sectors of medium-high purchasing power, which are not yet covered.

In [8], we indicate the figures of the Secretariat of Security, in addition to the Coexistence and Justice of the District, in the Ciudad Bolívar, Kennedy, Bosa, Usme, Rafael Uribe and San Cristóbal which are the most dangerous localities of Bogotá, in 2016 there were $61 \%$ of thefts of residences, $56 \%$ of theft to cars and $61 \%$ of theft to linear motorcycles, which are areas that have a very low level of surveillance systems (security cameras). Due to the insecurity that is experienced, citizens have developed methods to mitigate cases that mostly threaten the safety of citizens, one of the methods they have studied and that have high success rates, are community alarms, which are used to alert of events that have criminal origin such as theft. The "Community Alarm" application will allow to establish an alarm center only with the help of a cell phone that can be able to send SMS text messages. The application can function as a User or as a Server. The cell phone that is registered as a Server can add as many contacts as you like, these contacts will be the trained users of the system to be able to send the alarm signal in a situation of criminal origin. Thanks to the implementation of these mobile technologies for the benefit of security, several of the criminal events that happen daily in the localities are significantly improved. In conclusion, it is possible to highlight that it has been possible to favorably fulfill the objectives of the project, since it has gained an unbelievably valuable experience for the creation of cellular applications, in addition to the tools used in the creation of the same such as App Engine and Firebase.

\section{METHODOLOGY}

Figure 1 shows the flowchart of the alarm system activation.

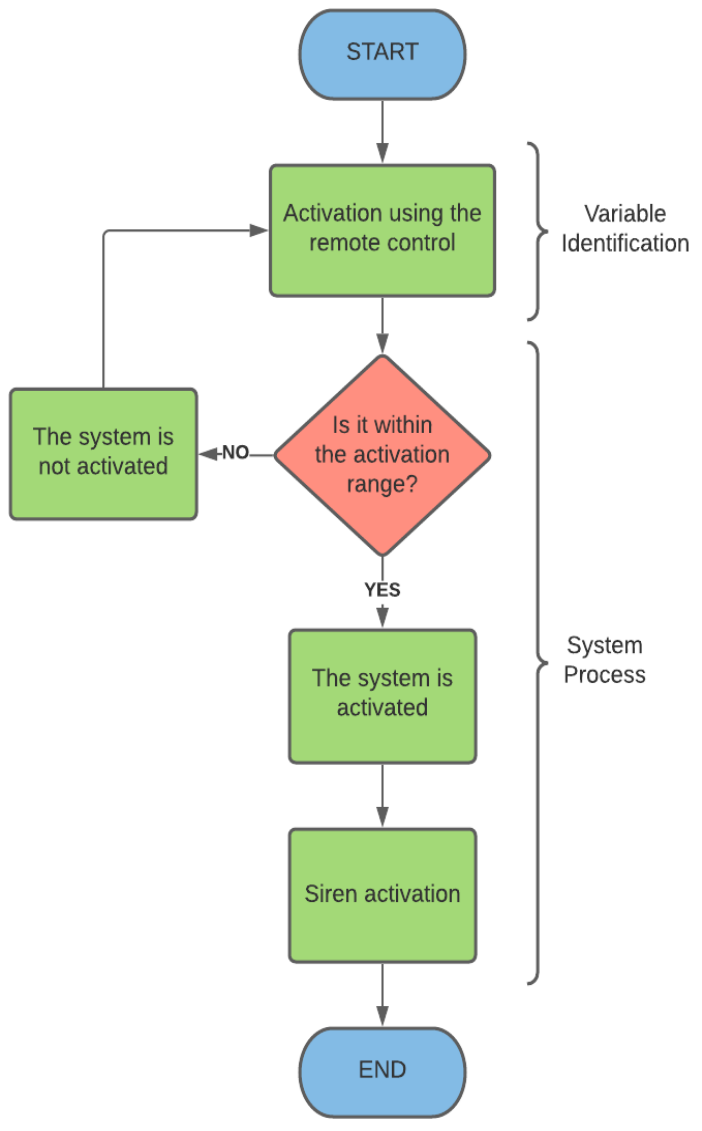

Fig. 1. Flowchart of the activation process in the remote alarm system.

\section{A. Variable identification}

For the realization of the project, it will be necessary to use an RF KR2201-4 module, which is usually used to control domestic equipment such as water pumps, garage doors, curtains, lamps, motors, etc. Table 1 will show the characteristics of the module.

TABLE 1.

RF MOdUle Features

\begin{tabular}{|l|l|}
\hline Model & KR2201-4 \\
\hline RF Frequency & $433 \mathrm{MHz}$ \\
\hline Operating voltage & AC $85 \mathrm{~V} \sim 220 \mathrm{~V}$ \\
\hline Sensitivity & $>97 \mathrm{dBm}$ \\
\hline Dimensions & $6.5^{*} 3.2^{*} 1.6 \mathrm{~cm}$ \\
\hline Control range & $>50 \mathrm{~m}$ (Free space) \\
\hline
\end{tabular}




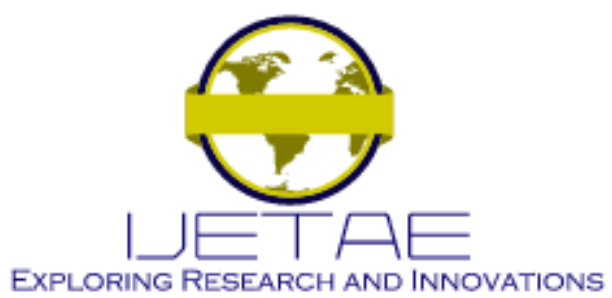

International Journal of Emerging Technology and Advanced Engineering Website: www.ijetae.com (E-ISSN 2250-2459, Scopus Indexed, ISO 9001:2008 Certified Journal, Volume 12, Issue 01, January 2022)

Its dimensions are favorable for its implementation, since it is small and therefore does not accept much space. Its stable performance and high reception sensitivity gives us the confidence for your application in this project. In addition to being taken as a model of the research work in [10] Figure 2 shows the RF module to be used.

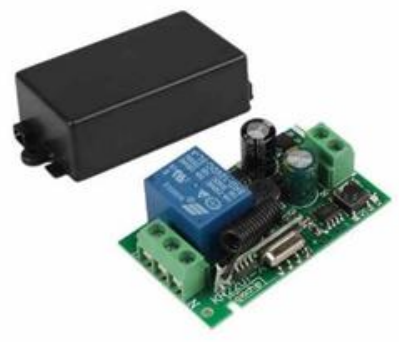

Fig. 2. RF Module KR2201-4 [11]

The RF KR2201-4 will be linked with their respective remote controls of the same frequency level, the characteristics of the same are shown in Table 2.

TABLE 2.

TRANSMITTER FEATURES

\begin{tabular}{|l|l|}
\hline Learning Code & 1527 \\
\hline RF Frequency & $433 \mathrm{MHz}$ \\
\hline Operating voltage & $\mathrm{DC} 12 \mathrm{~V}$ \\
\hline Transmission power & $+13 \mathrm{dBm}$ \\
\hline Dimensions & $5.4 * 2.9 * 0.9 \mathrm{~cm}$ \\
\hline Transmission distance & $>50 \mathrm{~m}($ Free space) \\
\hline
\end{tabular}

The remote control being small can be carried in any pocket next to our belongings, it even has a rotating hook to be able to attach it to a keychain. It has a silicone protector to obstruct the buttons and that they do not squeeze themselves when we take them with us.

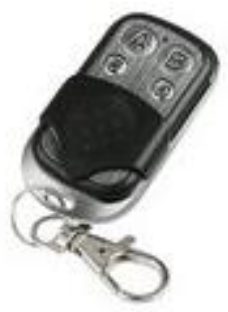

Fig. 3. Universal Control RF 433MHz [11]

The RF module KR2201-4 will be connected to a powerful siren and two different shades, the characteristics of the siren are presented in Table 3.
TABLE 3

FEATURES OF THE MERMAID

\begin{tabular}{|l|l|}
\hline Operating voltage & $\mathrm{AC} 220 \mathrm{~V}$ \\
\hline Power & $90 \mathrm{~W}$ \\
\hline Intensity & $125 \mathrm{~dB}$ \\
\hline Dimensions & $23.5 * 20 * 13 \mathrm{~cm}$ \\
\hline
\end{tabular}

This siren has a support which can be anchored to a surface for greater safety. In addition, it has 2 different tones one of ambulance siren and another of police siren.

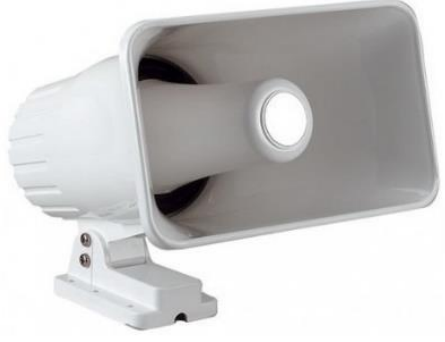

Fig. 4. Mermaid [12]

The system uses an audible alert so that in this way the wrongdoer is persuaded and the neighbors are warned of his criminal act, as is used in [13] in a home security system in order to warn that an alert is being presented.

\section{B. System Process}

For the operation of the system, it is necessary that RF module is within the range of the remote control or transmitter.

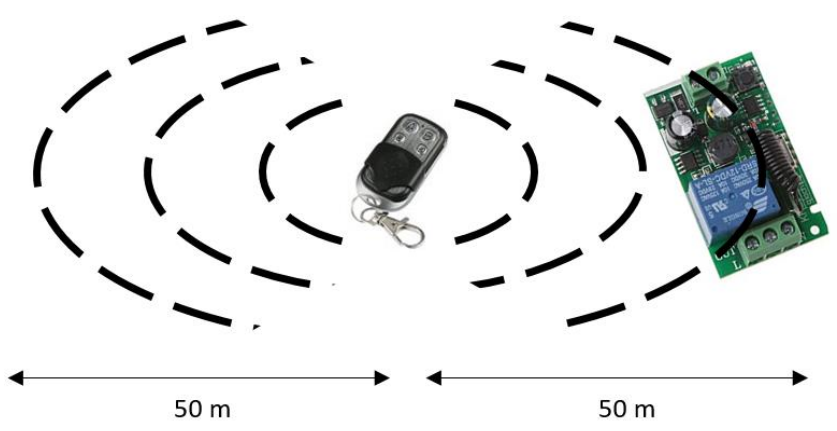

Fig. 5. Interconnection of the control to the module

If the signal emitted from the transmitter is not received by the RF receiver either because it is outside the working range which was indicated in Table 1, or because there are too many obstacles that prevent its link, then the system will not work, and the remote control would be inoperative until it can be located within the supported range. 


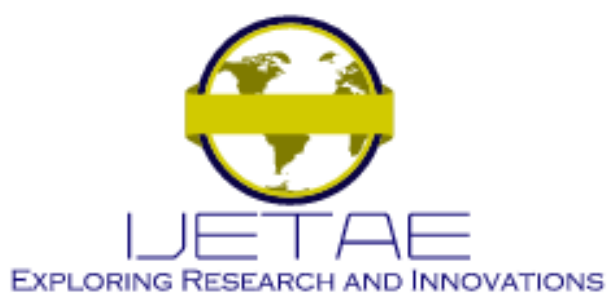

International Journal of Emerging Technology and Advanced Engineering

Website: www.ijetae.com (E-ISSN 2250-2459, Scopus Indexed, ISO 9001:2008 Certified Journal, Volume 12, Issue 01, January 2022)

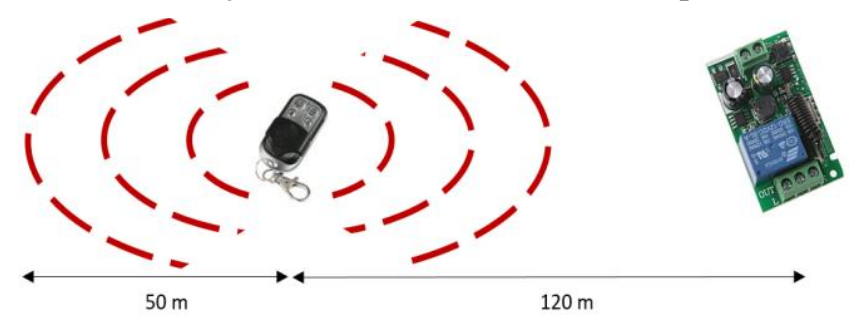

Fig. 6. Transmitter out of range of the module

If the RF module receives the signal emitted by the transmitter, then the system will be activated and the siren will be able to work, reaching distances of more than 200 meters, as shown in the following illustration.

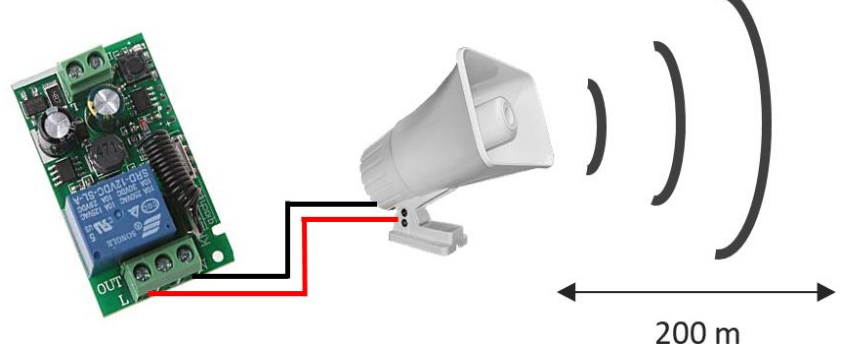

Fig. 7. Siren activation

The complete system working for the persuasion of a simulated criminal act is shown in Figure 8.

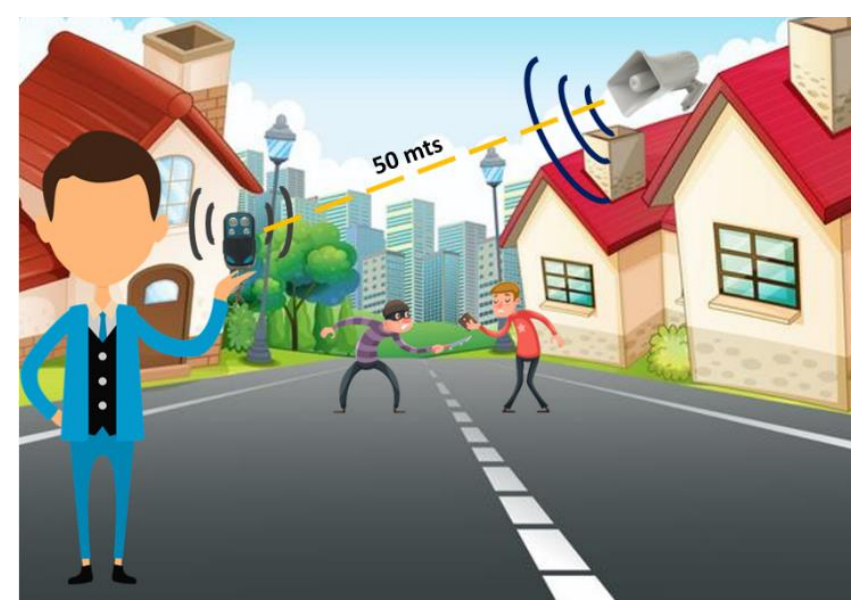

Fig. 8. Wireless alarm system.
As can be seen in the image, when a person witnesses a criminal act and this is within 50 meters of range of the RF module, then you can activate the siren by pressing the assigned button of your remote control similar to the operation mentioned in [14] , at that moment an activation signal will be sent to the relay located in the RF module, which will allow the passage of the current to the siren, this siren will be located in a strategic area of preference in a high house so that it can reach a radius of propagation greater than 200 meters. In this way it will be possible to persuade or frighten the evildoer and be able to thwart the criminal event.

To ensure the operation of the system in physics, we proceeded to simulate it in Proteus, because there was no radio frequency component, a radio frequency module library was downloaded.

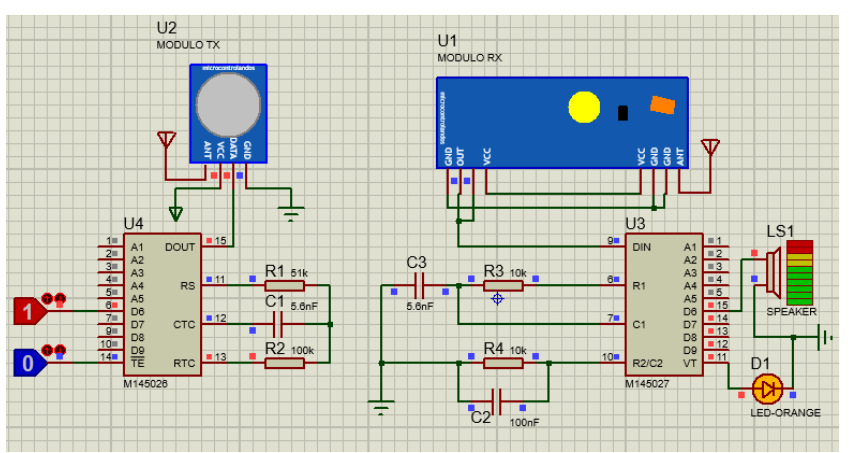

Fig. 9. Circuit in Proteus

Theimage shows the simulation of the circuit of the alarm system designed in proteus. The instant the D6 input of the transmitter is activated with a " 1 " and the D9 input of the same with a logical " 0 " the start-up is displayed in the SPEAKER of the receiver module and the functionality of the circuit.

\section{Results}

After having identified the characteristics of the receiver module, the transmitter, the siren, the operating distance of the control with the module, the range of the sound of the siren and the operating distances of the system we can collect in Table 4 the following characteristics. 


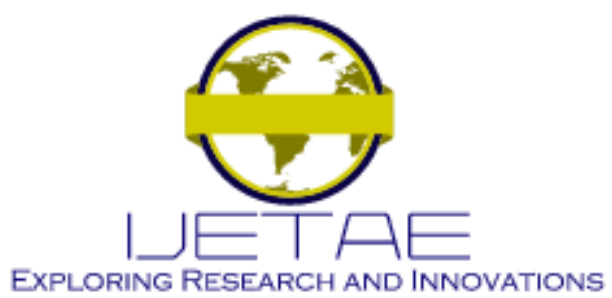

International Journal of Emerging Technology and Advanced Engineering

Website: www.ijetae.com (E-ISSN 2250-2459, Scopus Indexed, ISO 9001:2008 Certified Journal, Volume 12, Issue 01, January 2022)

TABLE 4.

OPERATING CHARACTERISTICS

\begin{tabular}{|l|c|}
\hline Operating distance & $60 \mathrm{~m}$ \\
\hline Siren range (sound) & $200 \mathrm{~m}$ \\
\hline Reaction time & $0.35 \mathrm{~s}$ \\
\hline Uptime (control) & $460 \mathrm{~h}$ \\
\hline
\end{tabular}

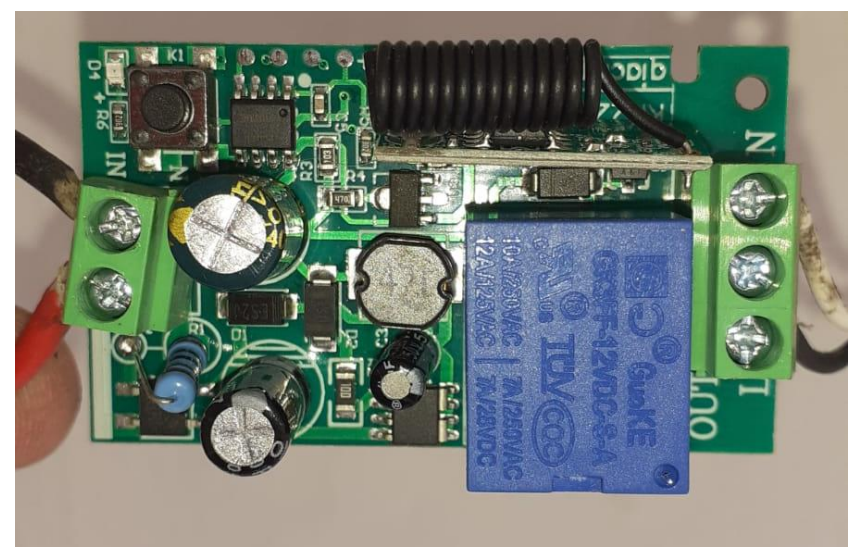

Fig. 10. RF Module

As shown in the Figura 10 the RF module has five terminals, two input to connect them to the 220VAC source and three output, of which only two are used for connection to the siren. It should be noted that the size of the module contributes to not using too much space in its installation.

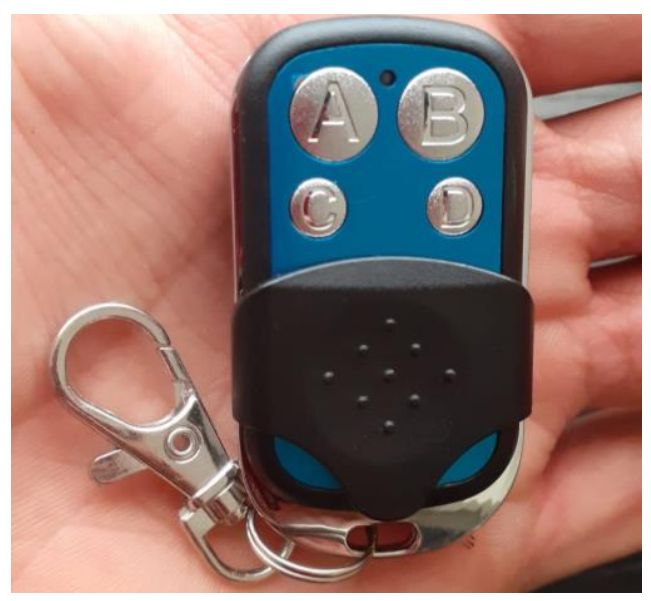

Fig. 11. Control RF
The size of the control is optimal for its transfer and storage in any pocket or wallet, in addition to having a hook keychain that improves its efficiency.

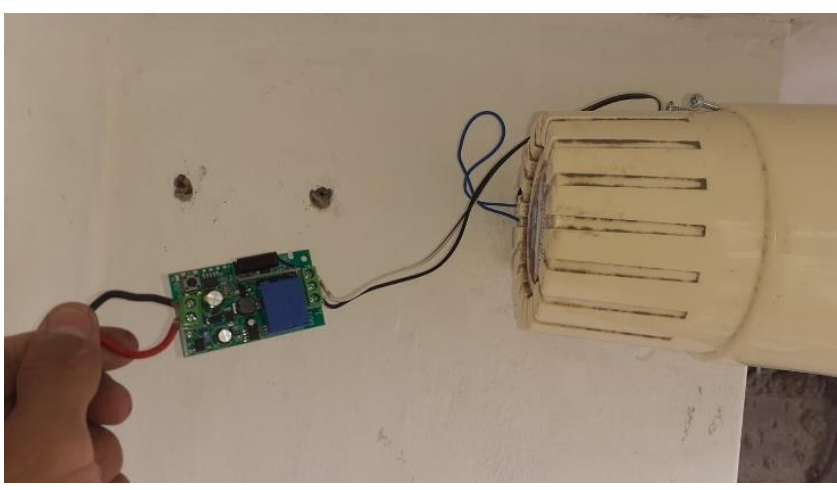

Fig. 12. Connecting the module to the siren

Figure 12 shows how the RFmodule is connected close to the siren to have a longer reaction time, in addition to the fact that it is necessary that it is in a strategic place so that it can be used from any point of the block.

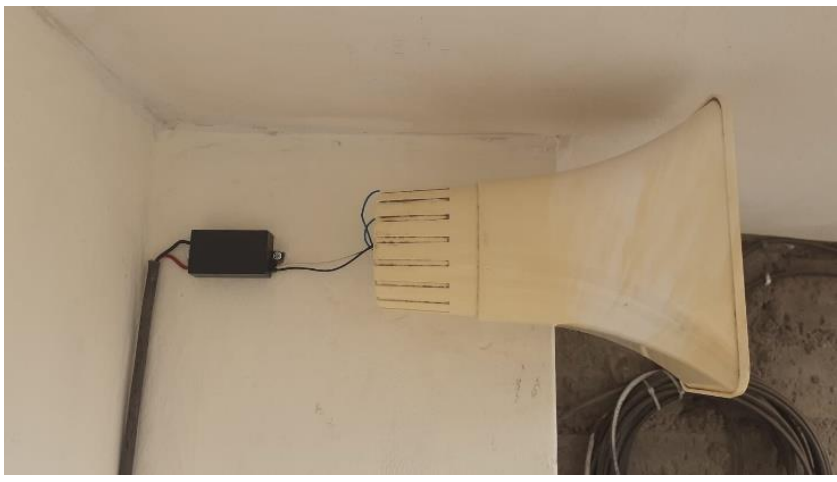

Fig. 13. Installation in the position of the alarm system.

For the installation, a protective housing was used that is included with the module, since being in the interperie is exposed to its rapid deterioration, in addition to mentioning that the electronic circuit is exposed from the back and can cause harmful electric shocks forpeople. 


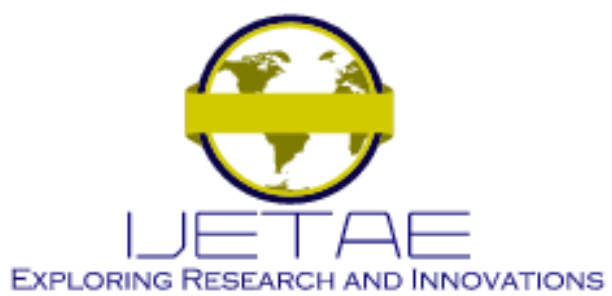

International Journal of Emerging Technology and Advanced Engineering

Website: www.ijetae.com (E-ISSN 2250-2459, Scopus Indexed, ISO 9001:2008 Certified Journal, Volume 12, Issue 01, January 2022)

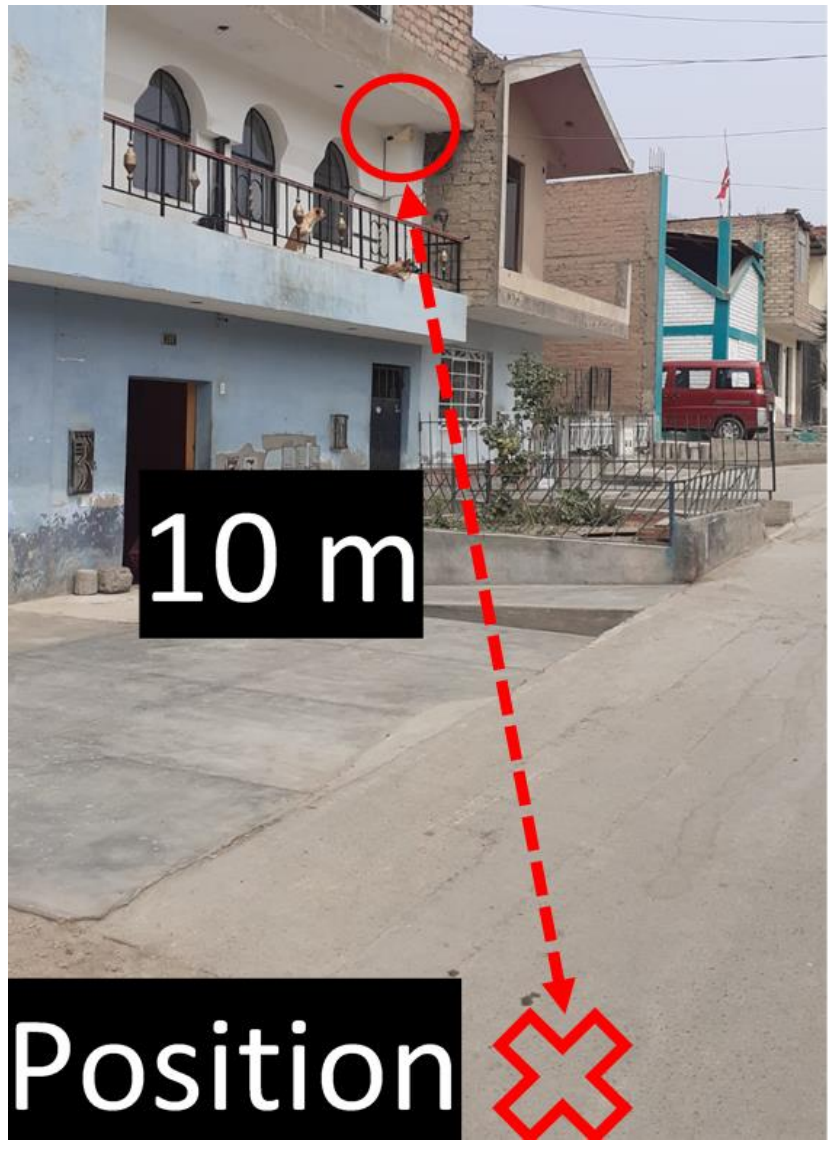

Fig. 14. Remote alarm system view point

The alarm is located on the second floor of the central house of the block, this to be able to have a central point on both sides of it and that can cover the entireblock. Figure 14 was taken 10 meters away from the alarm system, however when testing the siren it was possible to activate the siren from a distance of 60 meters in line of sight, which is enough to meet the objective of the system, remembering that the blocks measure an approximate of 100 meters and the siren located at the central point, 50 meters of the control range would be sufficient.

\section{DISCUSSION}

In this alarm system works it was opportune to use a siren to alert and to thwart theft attempts in addition to warning neighbors that a criminal act is occurring, contrary to the research work in [6] which focuses on the protection of homes using the alarm system.
The alarm will be executed by means of the control immediately with a limited range of action of the control of $50 \mathrm{~m}$, unlike the research work in [7], where it is based on communication through a mobile application which can cover a much greater range for communication between subscribers in the sector.

This system is designed so that at the moment in which the system is activated through the button the neighbors will automatically know that it is an alert that a criminal act is happening in the place, unlike the work in [8] where the alert is given by SMS through mobile devices, which can delay the notice about the criminal events that occur at the moment.

The alarm system implemented or in this research work considers it essential to have a low cost and a simple installation of the same to carry out the system in as much as possible of the population, unlike [15] where a higher cost of implementation is used and with greater technology for the security of a market.

\section{CONCLUSIONS AND RECOMMENDATIONS}

It is concluded that the system is functional for its purpose, it can be alerted in real time the moment in which something criminal act is detected in the area or in which we feel threatened by a suspicious individual.

It is concluded that the power of the siren causes a lot of noise, and this is necessary to be able to intimidate the evildoer and warn the neighbors of the block about the situation.

It is concluded that the system was in the best possible place for its operation because its range of work was limited had to be positioned at the crucial point of the block.

As a recommendation if a greater range of operation is required, the current module should be changed to one that has a larger work area, so that in this way the system can work in a wider area.

As a recommendation we can implement this system in a car, the 220VDC module would have to be changed to a 12 VDC adapter for the car and a siren of the same characteristics similar to what the author proposed in [16].

A limitation in this project was the issue of getting the controls because several neighbors did not want to have to be part of the alarm system because they do not trust that it can be useful for them. 


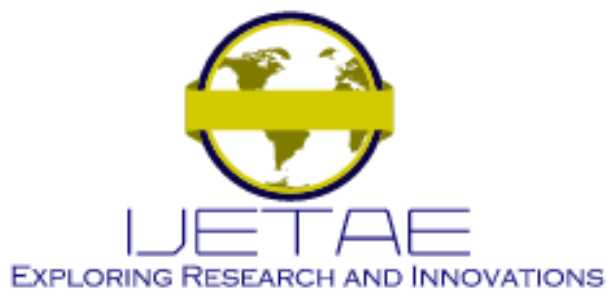

International Journal of Emerging Technology and Advanced Engineering Website: www.ijetae.com (E-ISSN 2250-2459, Scopus Indexed, ISO 9001:2008 Certified Journal, Volume 12, Issue 01, January 2022)

\section{REFERENCES}

[1] R. Muggah, "The Rise of Citizen Security in Latin America and the Caribbean," http://journals.openedition.org/poldev,vol. 9, Feb. 2018, doi: 10.4000/POLDEV.2512.

[2] B. E. Acosta Hiciano and L. G. Romero, "Alert of help in case of robbery or assault: support to victims through a technological device," Santo Domingo: Universidad Iberoamericana (UNIBE), Santo Domingo, 2020. Accessed: Sep. 19, 2021. [Online]. Available: https://repositorio.unibe.edu.do/jspui/handle/123456789/174.

[3] L. Chávez, "Lima has 39\% of the country's complaints," CORREO,Jun. 17, 2017. https://diariocorreo.pe/peru/lima-tiene-el39-de-las-denuncias-del-pais-756457/?ref=der (accessed Sep. 19, 2021).

[4] INEI, "Citizen Security Statistics," Lima - Peru, Jun. 2021. Accessed: Sep. 21, 2021. [Online]. Available: https://www.inei.gob.pe/media/MenuRecursivo/boletines/boletin_se guridad_nov20_abr21.pdf.

[5] INEI, "Statistical Yearbook of Crime and Citizen Security," Lima Peru, Jul. 2018. Accessed: Sep. 21, 2021. [Online]. Available: https://www.inei.gob.pe/media/MenuRecursivo/publicaciones_digita les/Est/Lib1534/libro.pdf.

[6] K. D. Gaibor Carrillo and F. A. Loor Morán, "Designing a low-cost wireless alarm system for the protection of type homes, in sectors of low economic resources of the city of Guayaquil."," University of Guayaquil, Guayaquil, 2018.

[7] B. E. Gómez Cumbajín, "'Estudio de sistemas de alarm comunitaria. Case study residential complex Ruiseñor 2,'" Pontificia Universidad Católica del Ecuador, Quito, 2018.

[8] J. García Buitrago and L. A. Colorado Aldana, "Sistema de Alarma Comunitaria Controlada desde Dispositivos Móviles," Universidad Distrital Francisco José de Caldas, Bogotá, 2018.
[9] Dominguez Sydney and Ramos Benjamín, "Telemetry and TeleRobotics: Implementation and Testing of Low-Power, Low-Cost RF Transceiver Modules in Basic Exploration Robot Prototypes, Based on Long-Range Performance," Anu. Do your research. Univ. Montemorelos,vol. 1, pp. 1-23, Aug. 2020, Accessed: Dec. 06, 2021. [Online]. Available: http://anuarioinvestigacion.um.edu.mx/index.php/a2020/article/view/ $121 / 104$.

[10] Aguayo Luis, "Implementation of an alarm system through the arduino platform through mobile telephony in the Dean's Office of the Faculty of Technical Sciences," Universidad Estatal del Sur de Manabí, Manabí, 2018.

[11] Oliveira David and Batista Laura, "Analysis of RF $433 \mathrm{MHz}$ communication in home monitoring prototype," Instituto Federal de Educação, Ciência e Tecnologia do Amazonas,Amazonas, pp. 1-7, Mar. 30, 2018

[12] Gold Agents, "PA Siren Speaker Electronic Siren Outdoor Speaker (JHW-508) - GoldAgent," 2017. https://www.goldagents.com/product.aspx?id=14490798 (accessed Dec. 05, 2021).

[13] J. A. RUIZ SANDOVAL, "Design and implementation of an intrusion alarm system based on the ESP-NOW protocol of the Internet of Things," Repos. Inst. UNTELS,pp. 1-128, 2021, Accessed: Dec. 05, 2021. [Online]. Available: http://repositorio.untels.edu.pe//handle/123456789/594.

[14] A. Calonge, "Design of a ModBUS/RS485 to RF gateway module in the IoT-oriented ISM bands," Universitat Politècnica de València, Valencia, 2018.

[15] K. G. Chicaiza Guachi, "Sistema de alarma comunitaria para el mercado San Juan de la Ciudad de Santiago de Píllaro," Universidad Técnica de Ambato. Faculty of Systems, Electronics and Industrial Engineering. Electronic Engineering and Communications Degree, Ambato, 2020.

[16] M. Moreno Rodríguez, "Diseño e implementación de un sistema de alarma para coches.," Universidad Autonoma de Madrid, Madrid, 2017. 